\title{
A Comparison Study of the Metal Oxide Catalysts for the Conversion of Used Cooking Oil into High Grade Chemicals
}

\author{
Wali Ullah, Naseer Ahmed Khan*, Naveed ul Hasan Syed and Muddasar Habib \\ Department of Chemical Engineering, University of Engineering and Technology (UET) Peshawar, \\ Khyber Pakhtunkhwa (KPK), 25120, Pakistan. \\ *Corresponding Author Email: naseerahmedkhan@uetpeshawar.edu.pk \\ Received 20 June 2020, Revised 26 October 2020, Accepted 25 November 2020
}

\begin{abstract}
Cracking of edible oils occurs at high temperature and forms valued low molecular weight chemical species. The aim of the current study was to find a catalyst which can break these heavy molecules at the lower ranges of temperatures. From the analysis prospective, the non-condensable hydrocarbons (gaseous product species) were not determined and reactions study was carried out in a batch reactor. There was no evident conversion up to a temperature of $450{ }^{\circ} \mathrm{C}$ in the absence of catalyst whereas the reaction mixture was left inside a batch reactor for a long duration of an hour. Reaction parameters, such as catalyst types $\left(\mathrm{ZnO}\right.$ and $\left.\mathrm{Al}_{2} \mathrm{O}_{3}\right)$, amount of catalyst, reaction temperature, residence or holding time, and heating rate to reach a reaction temperature were systematically examined. Powdered form of catalyst samples $\left(\mathrm{ZnO}\right.$ and $\left.\mathrm{Al}_{2} \mathrm{O}_{3}\right)$ were characterized by using XRD, EDX, and Nitrogen adsorption isotherms. Temperatures studied over $\mathrm{ZnO}$ catalyst were $400{ }^{\circ} \mathrm{C}, 425{ }^{\circ} \mathrm{C}, 450{ }^{\circ} \mathrm{C}, 475{ }^{\circ} \mathrm{C}$, and $500{ }^{\circ} \mathrm{C}$. The maximum oil conversion was $81 \%$ at a temperature of $450{ }^{\circ} \mathrm{C}$. We observed that the conversion increases from $400{ }^{\circ} \mathrm{C}$ to $450{ }^{\circ} \mathrm{C}$, whereas above $450{ }^{\circ} \mathrm{C}$ it starts to decrease. However, in comparison to $\mathrm{ZnO}$ catalyst the reaction rate was much higher over the $\mathrm{Al}_{2} \mathrm{O}_{3}$, i.e. a considerable conversion occurred at lower ranges of temperatures. Thus here a different set of temperatures $\left(330{ }^{\circ} \mathrm{C}, 370{ }^{\circ} \mathrm{C}, 390{ }^{\circ} \mathrm{C}, 410{ }^{\circ} \mathrm{C}\right.$, and $430^{\circ} \mathrm{C}$ ) were used. When reacting for an hour at a temperature of $390{ }^{\circ} \mathrm{C}$, and in the presence of 8 wt. $\%$ of $\mathrm{Al}_{2} \mathrm{O}_{3}$ (same catalyst mass was used in $\mathrm{ZnO}$ reacting system) the conversion reached to 71 $\%$. Above $390{ }^{\circ} \mathrm{C}$ the conversion decreased. Over both tested metal oxide catalysts the caloric value, density, flash point, and kinematic viscosity of the liquid product species were similar to petro fuels. The XRD and EDX signature of the catalyst samples corresponds to the standard $\mathrm{ZnO}$ and $\mathrm{Al}_{2} \mathrm{O}_{3}$ patterns. Finally, when compared to $\mathrm{ZnO}$ the better activity over the $\mathrm{Al}_{2} \mathrm{O}_{3}$ (higher conversion at lower temperature) catalyst can be linked with a high external surface area.
\end{abstract}

Keywords: Used edible oils, $\mathrm{ZnO}, \mathrm{Al}_{2} \mathrm{O}_{3}$, Catalytic cracking.

\section{Introduction}

Proper disposal or the conversion of used cooking oil into lighter organic molecules is still widely studied subject [1]. These edible oils are the essential part of our daily cooking, and the annual consumption is in billions of tons. Most of the edible oils are extracted from different plant seeds (soybean, sunflower, etc.). The physiochemical properties changes during frying and thus edible oils are usually wasted after frying or in other words not properly utilized [2]. In most of the underdeveloped countries, a major portion of the cooking oil is reused in street food outlets, and is therefore a serious health concern. These low valued hydrocarbon molecules (used oil) can be chemically converted into high grade chemicals, such as biofuels, glycerine, free fatty acids, and many solvents 
[3]. Presently most of the researchers are studying the compatibility of the plant oils as an alternative fuel, and here we are following the same theme.

The International community has adopted a policy of a sustainable development goals in a united nation summit, which was held in New York between 25 - 27 September, 2015. As a way forward seventeen goals were set and promised to achieve before 2030 for the development of the whole world. The objectives are; No poverty, zero hunger, good health, education of all, gender equality, clean water, clean energy, economic growth, industry and infrastructure, no inequality, sustainability, responsible consumption, climate action, better life under water, healthy life on the land, peace and justice, and finally close partnership between the agreeing countries. The details of these segments are beyond the scope of the present work, but we may say that two main concerns are addressed in this paper which are climate change and clean energy. With reference to clean energy, the usual inclination is more towards the solar electric energy, however biofuels play a vital role in terms of cheap and environmentally sustainable fuel.

Fuels are combustible fluids (gas and liquid) and solids. No doubt the economy of any country is dependent on the availability of cheap fuels. From the environmental prospective, the fossil fuel combustion reactions are mainly responsible for the environmental degradation $[1,4]$. The use of the vegetal fuels, for example different plant seed oils takes carbon dioxide $\left(\mathrm{CO}_{2}\right)$ from the atmosphere during the growth and is a good candidate for the combustion reactions $[5,6]$. Theoretically, different hydrocarbons, for example plant seed (edible and non-edible) oils, sugar, cellulosic biomass, organic waste, algae, algae oil can produce heat during combustion $[2,3]$. When compared to petro- fuels, these renewable fuels are biodegradable, non-toxic, and most importantly consume carbon oxide [7, 8]. On the other hand, the use of neat edible oil as a fuel is a concern as reported by many international nongovernmental bodies, however the utilization of used cooking oil will not compete with the food supply chain and is safer to be converted into other valuable chemical species.

We are aware that the consumption of the edible oil is continuously increasing and in return one can expect more amount of wasted oils [9-12]. With basic physical treatments, the used edible oil does not necessarily regain the actual composition or healthiness and therefore should be chemically treated for other useful applications [13]. Several methods, for example fermentation, emulsification, transesterification, pyrolysis, and catalytic cracking have been tested in order to convert the used cooking oil into bio fuels and chemicals. Catalytic cracking is perhaps more unique and suitable route for the conversion reactions [14-19].

Catalytic cracking is not a new subject and this technology is widely used in petro refinery industries for the conversion of crude oil into olefins, paraffin's gasoline, diesel, and kerosene $[20,21]$. The same catalytic principle is applied for the conversion of heavy triglyceride molecules. Mostly the cracking is carried out in presence of a limited air (to avoid unnecessary oxidation) and from the mechanism prospective initially the triglyceride molecule detaches fatty acid chains and then in a second phase the breaking of fatty chains occurs and forms lighter species [18]. Different catalysts, for example zeolites, metal oxide, and transition metals have been used for the kinetic study of the plant oil cracking reactions [18]. Cooking oil/animal fats are actually triglyceride molecules and each molecule contains three fatty acid chains connected to a glycerol [22]. 
Fatty acid chains are mostly myristic acid (C14:0), palmitic acid (C16:0), stearic acid (C18:0), oleic acid (C18:1), linoleic acid (C18:2), linolenic acid (C18:3), and eicosanoic acid (C20:0) [22]. In catalytic cracking the heavy fatty chains/glycerol are chemically converted into lighter and useful hydrocarbon compounds. The mechanism can be presented as;

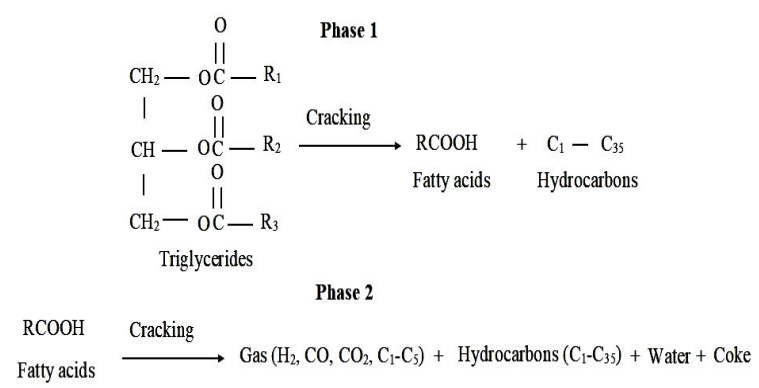

Moreover, energy demand is
continuously increasing because of industrialization, agriculture, and population growth. Approximately in the next 100 years the world oil reserves will be very less. So, it is the time to investigate new alternative oil sources [18]. Governments and the individual research groups are working together to build a sustainable package for the use of renewable fuels on the priority basis, and to lessen the dependence on the fossil fuels by increasing the mix of renewable fuels in the total energy system. In this study we have determined the catalytic capability of two different metal oxide catalysts and the optimal reaction conditions for the conversion of used cooking oil into lighter organic species.

\section{Materials and Method Chemical and Reagents}

Used cooking oil of blackish appearance (Fig. 1) was collected from a local frying shop. Approximately $500 \mathrm{~mL}$ of oil was taken out in a beaker from a glass bottle container. The beaker containing used oil (500 $\mathrm{mL}$ ) was placed on a desk in order to settle down the heavy suspend particles. The upper portion of relatively clean cooking oil was then transferred into a separate beaker, whereas viscous settled layer was left behind in the first beaker. The comparatively cleaned cooking oil was further passed through a Whatman filter paper (grade 1) to remove other tiny suspended particles. These all cleaning steps enhanced the yellowish appearance of the dark colored oil (Fig. 1).

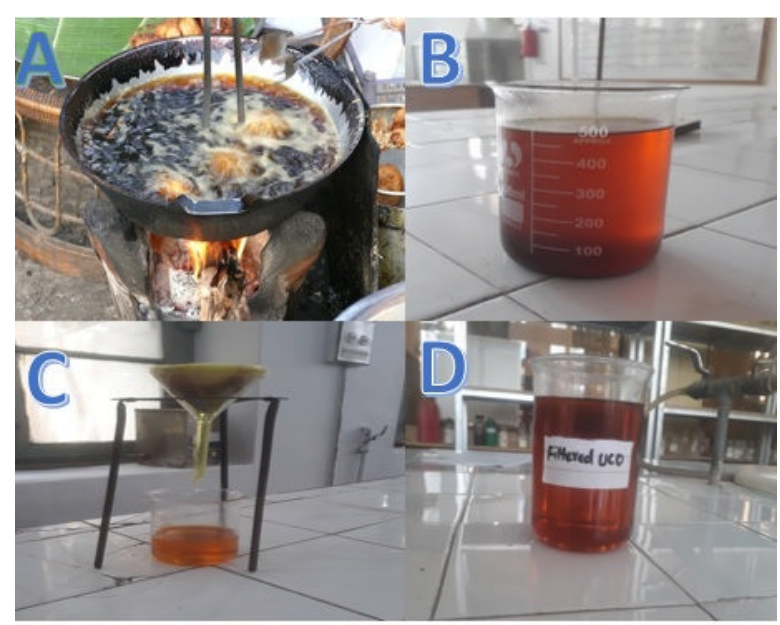

Figure 1. Steps followed (A, B, C, and D) to settle and then separate the suspended particles from used edible oil.

\section{Activity Tests}

As shown in Fig. 2, a homebuilt experimental setup was used for the reaction study. Round bottom Pyrex flask was used as a reactor. The produced gaseous hydrocarbons were cooled in a condenser and then collected in a separate flask. For safety purpose, an opening was made just before the collecting flask in order to exhaust the pressurized noncondensable hydrocarbons otherwise there will a pressure buildup inside the condenser.

In each experiment a $30 \mathrm{~g}$ of cleaned cooking oil was used as a reactant. The temperature of the reactor was increased to a set temperature with a ramp rate of $10^{\circ} \mathrm{C}$ or 5 ${ }^{\circ} \mathrm{C}$ per min. The whole range of reaction temperature was maintained between $330{ }^{\circ} \mathrm{C}-$ 
$550{ }^{\circ} \mathrm{C}$. Catalytic activity was analyzed over $\mathrm{ZnO}$ and $\mathrm{Al}_{2} \mathrm{O}_{3}$ catalyst. For the study of catalyst mass, a varied catalyst concentration (4 wt \% - 12 wt \%) was also used. Oil and catalyst was thoroughly mixed in a reactor by using a magnetic stirrer and the reacting system was almost homogeneous. The yield of the product liquid was calculated by using following equation.
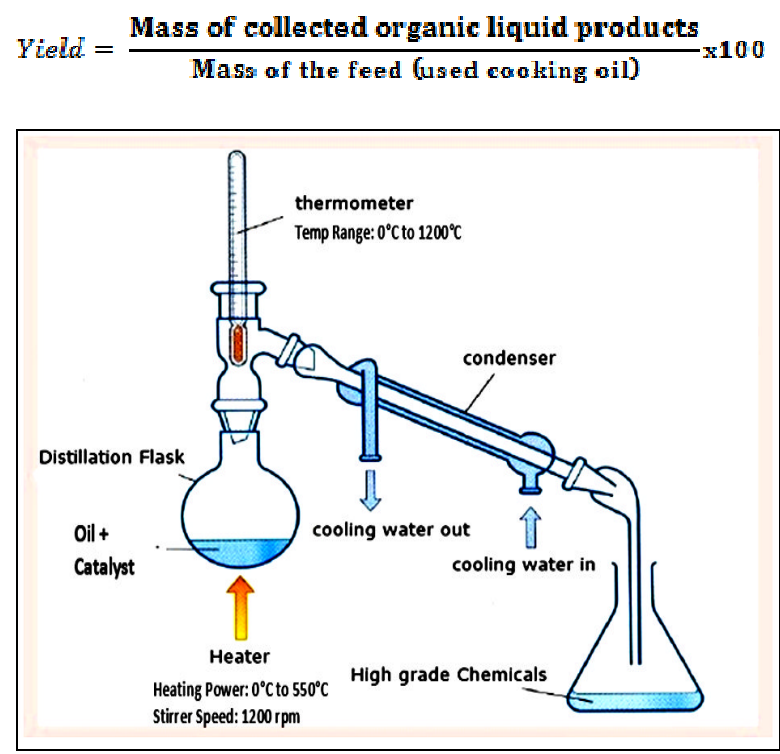

Figure 2. Homebuilt experimental setup

\section{Reaction product (hydrocarbon) analysis}

Reaction product species was examined by using a gas chromatograph (GC) and mass spectrometer (MS). Thermo Scientific (GC-MS), model Thermo Scientific GC Focus Series and Thermo scientific MS DSQ II, with inbuilt Software version: 2.0.7, was used. The oven consists of TR-MS capillary column of internal diameter $0.25 \mu \mathrm{m}$, film thickness $0.25 \mu \mathrm{m}$, dimension $30 \mathrm{~m} \times 0.2$ $\mathrm{m}$, and length of $30 \mathrm{~m}$. Helium (He) was used as a carrier gas. In presence of helium flow, the oven temperature was increased to a sample injection temperature $\left(250{ }^{\circ} \mathrm{C}\right)$ by following two different ramp rates. First, the oven temperature was increased from $50{ }^{\circ} \mathrm{C}$ to
$150{ }^{\circ} \mathrm{C}$ with a heating rate of $25^{\circ} \mathrm{C} / \mathrm{min}$. The holding time at $150^{\circ} \mathrm{C}$ was about $1 \mathrm{~min}$. From $150{ }^{\circ} \mathrm{C}$ to $250{ }^{\circ} \mathrm{C}$, the ramp rate of $10^{\circ} \mathrm{C} / \mathrm{min}$. All oil samples were injected at a temperature of $250^{\circ} \mathrm{C}$ and at 1 atmospheric pressure.

\section{Catalyst characterization}

Characterization techniques, X-ray diffraction and nitrogen adsorption isotherms were used for the characterization of the metal oxide catalysts. X-ray diffractometer is a powerful analytical instrument used for the crystal analysis. Braggs equation determines the length between different crystal planes. The X-rays diffraction pattern of powdered samples were compared in diffractometer (Model: JEOL (Japan), voltage: $20-40 \mathrm{kv}$, Current: 2.5-30 mA, and X-ray Wavelength: $1.5418 \AA(\mathrm{CuKa}))$. The measured diffraction angles $(2 \theta)$ of the X-rays were between 0 to 160. The sample analysis was carried out at room temperature and pressure. Copper $\mathrm{Cu}(\mathrm{K} \alpha)$ was used as a radiation source. Whereas, nitrogen adsorption on catalyst samples at a temperature of $-175^{\circ} \mathrm{C}$ was carried out for the determination of surface morphology. Equilibrium maintained for each admitted molecule and adsorbate concentration. Prior to adsorption analysis, catalyst samples were heated to a temperature of about $105{ }^{\circ} \mathrm{C}$ in an inert environment in order to remove the adsorb gases. NOVA eSeries, model NOVA220e Quantachrome, USA, was used to determine surface morphology.

\section{Results and Discussion}

The main objective of the study was to find a catalyst better in terms of conversions at lower temperature ranges. In general, the results and discussion section is divided into kinetics and catalyst characterization sections. 


\section{Reactions Kinetics}

Apparently, a high temperature is needed for the conversion of the cleaned edible oil. For overall catalyst comparison, a same mass of $2.4 \mathrm{~g}$ ( $8 \mathrm{wt} \%$ of oil) of $\mathrm{ZnO}$ or $\mathrm{Al}_{2} \mathrm{O}_{3}$ was used for the kinetic study. Fig. 3 is presenting the comparison of the reaction activity over $\mathrm{ZnO}$ and $\mathrm{Al}_{2} \mathrm{O}_{3}$ catalyst. Different set of temperature ranges, for example over $\mathrm{ZnO}$ the catalytic cracking experiments were carried at $400^{\circ} \mathrm{C}, 425^{\circ} \mathrm{C}$, $450^{\circ} \mathrm{C}, 475^{\circ} \mathrm{C}$ and $500^{\circ} \mathrm{C}$. During these experiments it was observed that there is no conversion before $400^{\circ} \mathrm{C}$. Total conversion at $400^{\circ} \mathrm{C}$ was $38 \%$ and followed the increased trend up to $450^{\circ} \mathrm{C}$. In these reactions the set temperature was achieved with a ramp rate of $10{ }^{\circ} \mathrm{C} / \mathrm{min}$. The maximum conversion over $\mathrm{ZnO}$ was about $80 \%$ and at a temperature $450^{\circ} \mathrm{C}$. However, further increase in the temperature caused a decrease in the catalytic activity. The decrease trend is because of limited catalyst and reactant species interactions. Since the mass transfer phenomenon is dominant at high turbulent system and thus most probably the reactant species does not have enough time to interact with the catalyst active sites. Over $\mathrm{Al}_{2} \mathrm{O}_{3}$, experiments were conducted at $330^{\circ} \mathrm{C}, \quad 370^{\circ} \mathrm{C}, \quad 390^{\circ} \mathrm{C}$, $410{ }^{\circ} \mathrm{C}$, and $430{ }^{\circ} \mathrm{C}$. The gaseous product starts to form at $330^{\circ} \mathrm{C}$. The conversion trend increased from $330^{\circ} \mathrm{C}$ to $390^{\circ} \mathrm{C}$. The temperature of reacting system was increased with a same rate of $10{ }^{\circ} \mathrm{C} / \mathrm{min}$. Above $390^{\circ} \mathrm{C}$ the conversion decreased because of limited species and catalyst interactions. The maximum conversion recorded was about $71 \%$ and at a temperature of $390^{\circ} \mathrm{C}$. Whereas, there was no conversion over $\mathrm{ZnO}$ below $400^{\circ} \mathrm{C}$, confirming the fact that catalyst morphology plays an important role in the conversion reactions.

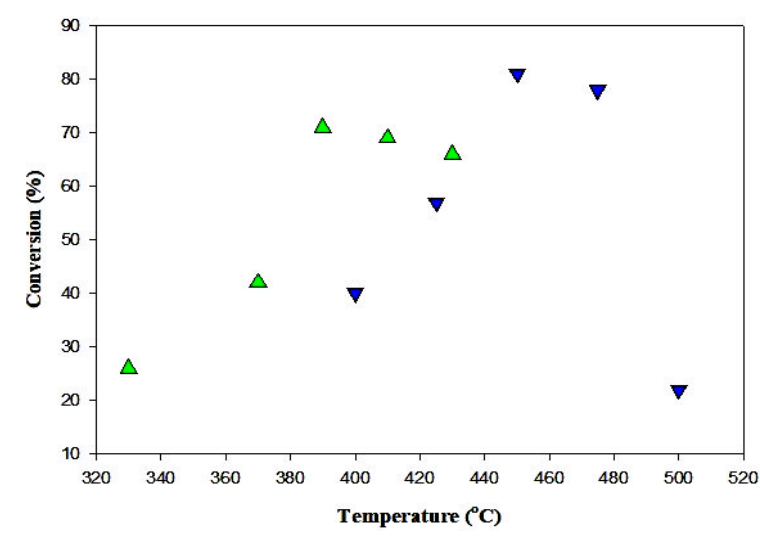

Figure 3. Conversion verses temperature over $\mathrm{ZnO}(\nabla)$ and $\mathrm{Al}_{2} \mathrm{O}_{3}(\Delta)$

The effect of the catalyst loadings (calculated on the basis of oil weight) on the conversion reaction was also studied. Different amount of powdered mass, i.e. 2 wt $\%, 4 \mathrm{wt} \%, 6 \mathrm{wt} \%, 8 \mathrm{wt} \%$, and $12 \mathrm{wt} \%$ of $\mathrm{Al}_{2} \mathrm{O}_{3}$ catalyst was used in a set of experiments. As shown in (Fig. 4), the activity was higher in presence of $8 \mathrm{wt} \%$ of catalyst mass. Any increase or decrease in the catalyst mass appears to have a negative impact on the rate of reaction. A similar observation was found in a published work [23]. Furthermore, since the reactions were conducted in a batch reactor, therefore the residence time may also upset the amount of product yield.

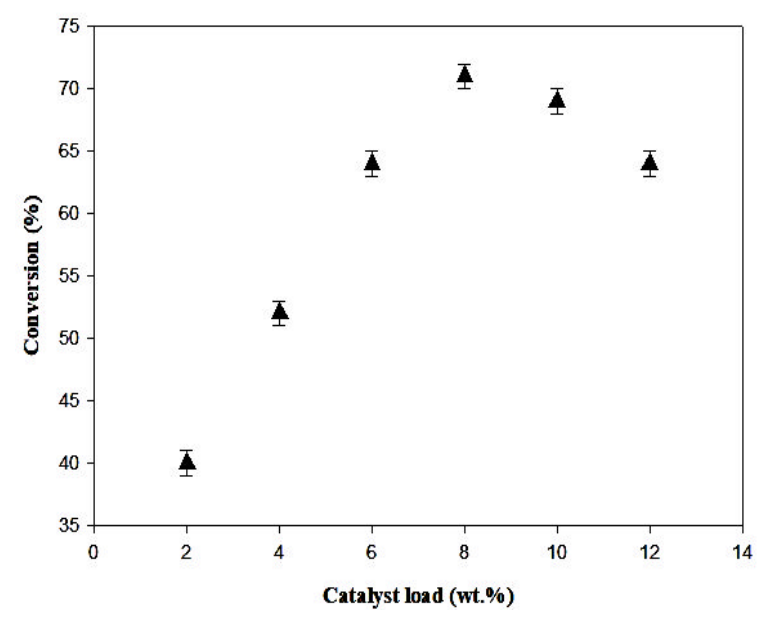

Figure 4. Effect of catalyst loading on the product yield at a temperature of $390{ }^{\circ} \mathrm{C}$ while having a residence time of $60 \mathrm{~min}$ 
Thus in separate set of experiments, the reacting species were left inside the reactor for $30 \mathrm{~min}, 40 \mathrm{~min}, 50 \mathrm{~min}$ and $60 \mathrm{~min}$ to see any variations in the mass of the collected product. There was not much difference in the quantity of the oil products and therefore one may conclude that the $30 \mathrm{~min}$ time is enough for the catalytic conversion reaction.

Literature suggest variations in the quantities of product when heated to a reaction temperature differently [24]. Therefore, in order to study the effect of heating rate the reaction temperature was achieved with ramp rate of $5{ }^{\circ} \mathrm{C} / \mathrm{min}$ and $10{ }^{\circ} \mathrm{C} / \mathrm{min}$ as shown in the Fig. 5. Our results show that there is not much difference when reaching to a conversion temperature at different rates. However, there was a notable difference at a temperature of $390^{\circ} \mathrm{C}$. Moreover, the selectivity of the reaction product composition may vary when following different heating rate, however it was not the main focus of the current study [25].

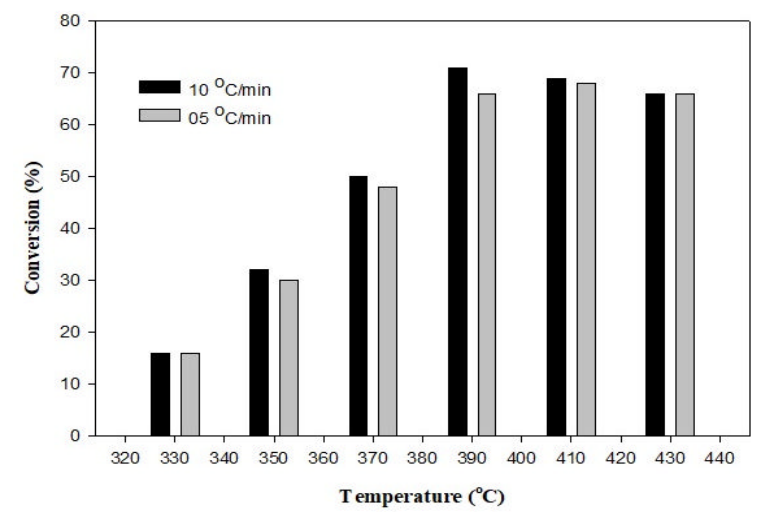

Figure 5. Effect of the heating rate on the oil conversion at varied temperature and in presence of $8 \mathrm{wt} \%$ of catalyst mass

Regarding the product species, a light colored hydrocarbon mixture was obtained in a product flask. The composition of the produced oil was analyzed in a GC-MS. Peaks having different retention time showed the presence of a number of organic composition and when fragmented in mass spectrometer
(MS) a possible composition appeared as given in Table 1. Furthermore, common fuel properties such as density, calorific value, kinetic viscosity, and flash point were very much in a range of standard numbers, i.e. 0.8 $\mathrm{g} / \mathrm{cm}^{3}, 38 \mathrm{MJ} / \mathrm{kg}, 3.6 \mathrm{~mm}^{2} / \mathrm{sec}$. and $88^{\circ} \mathrm{C}$, respectively.

Table 1. Composition of collected product species.

\begin{tabular}{llcc}
\hline $\begin{array}{c}\text { Retention } \\
\text { Time } \\
(\text { min) }\end{array}$ & \multicolumn{1}{c}{ Compound } & $\begin{array}{c}\text { Peak area } \\
(\%)\end{array}$ & Formula \\
\hline 0.9 & 1-Heptene & 5.96 & $\mathrm{C}_{7} \mathrm{H}_{14}$ \\
1.45 & Octane & 5.02 & $\mathrm{C}_{8} \mathrm{H}_{18}$ \\
2.12 & Nonane & 4.79 & $\mathrm{C}_{9} \mathrm{H}_{20}$ \\
2.8 & Decane & 4.01 & $\mathrm{C}_{10} \mathrm{H}_{22}$ \\
3.45 & Dichloroacetic acid & 5.47 & $\mathrm{C}_{15} \mathrm{H}_{28} \mathrm{Cl}_{2} \mathrm{O}_{2}$ \\
4.06 & 3-Hexadecyloxycarbonyl-5 & 4.95 & $\mathrm{C}_{24} \mathrm{H}_{45} \mathrm{~N}_{2} \mathrm{O}_{3}$ \\
4.61 & 1-Dodecanol, 2-methyl-, $(\mathrm{S})-$ & 5.49 & $\mathrm{C}_{15} \mathrm{H}_{32} \mathrm{O}$ \\
5.18 & n-Decanoic acid & 10.26 & $\mathrm{C}_{10} \mathrm{H}_{20} \mathrm{O}_{2}$ \\
5.85 & 2-Hexyl-1-octanol & 10.22 & $\mathrm{C}_{14} \mathrm{H}_{30} \mathrm{O}$ \\
6.69 & Oleic Acid & 8.92 & $\mathrm{C}_{18} \mathrm{H}_{34} \mathrm{O}_{2}$ \\
8.03 & 8-Heptadecene & 10.43 & $\mathrm{C}_{17} \mathrm{H}_{34}$ \\
9.27 & 13-Heptadecyn-1-ol & 0.88 & $\mathrm{C}_{17} \mathrm{H}_{32} \mathrm{O}$ \\
9.62 & Octadecene & 2.01 & $\mathrm{C}_{18} \mathrm{H}_{36}$ \\
9.97 & Hexadecanethiol & 0.73 & $\mathrm{C}_{16} \mathrm{H}_{34}$ \\
11.62 & 9-Nonadecene & 2.46 & $\mathrm{C}_{19} \mathrm{H}_{38}$ \\
12.04 & Octadecane & 1.88 & $\mathrm{C}_{18} \mathrm{H}_{38}$ \\
14.04 & n-Hexadecanoic acid & $\mathrm{C}_{16} \mathrm{H}_{32} \mathrm{O}_{2}$ \\
16.2 & 1-Heneicosanol & $\mathrm{C}_{21} \mathrm{H}_{44} \mathrm{O}$ \\
\hline 18.6 & Oleic Acid & $\mathrm{C}_{18} \mathrm{H}_{34} \mathrm{O}_{2}$ \\
\hline
\end{tabular}

\section{Catalyst Characterization}

As shown earlier (Fig. 3), the activity over $\mathrm{Al}_{2} \mathrm{O}_{3}$ and $\mathrm{ZnO}$ is very much different. Crystal structures of $\mathrm{ZnO}$ and $\mathrm{Al}_{2} \mathrm{O}_{3}$ were examined by using $\mathrm{X}$-Ray diffraction analyzer technique. During XRD analysis, peaks at different angles appeared as shown in Fig. 6. The peak pattern of both samples correspond to the standard images [26-28]. The chemical analysis was confirmed with the EDX technique and contained one dominant phase or had more than $90 \%$ of one type of composition (EDX data not shown). 


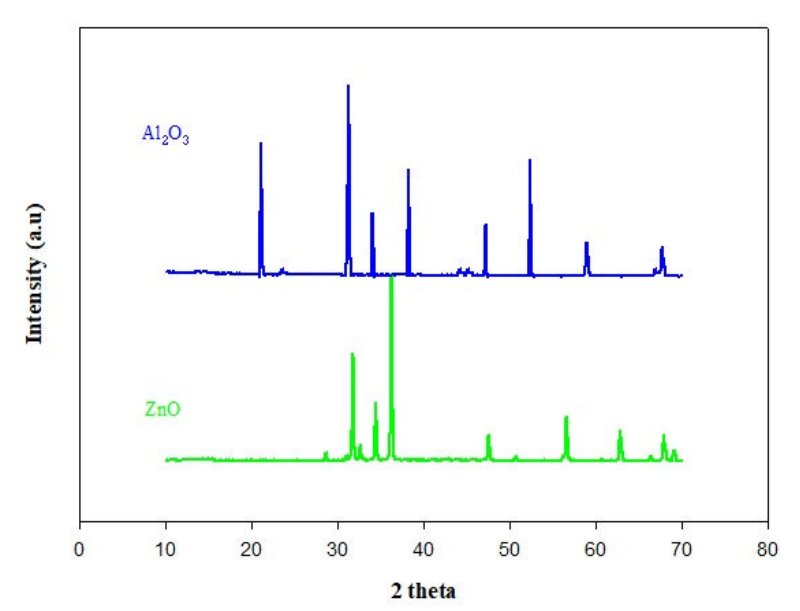

Figure 6. XRD pattern of $\mathrm{ZnO}$ and $\mathrm{Al}_{2} \mathrm{O}_{3}$

For surface area comparison, the adsorption of nitrogen gas (bottle gas) at standard temperature pressure was carried over $\mathrm{ZnO}$ and $\mathrm{Al}_{2} \mathrm{O}_{3}$ samples. These samples were activated prior to adsorption studies. At each adsorption state or data point, the free nitrogen gas was given enough time to attain the equilibrium. The dozing of the adsorbent gas was carried out at a room temperature whereas the adsorbate (catalysts) maintained a temperature of $-175{ }^{\circ} \mathrm{C}$ (liquid nitrogen). The relationship between volume adsorbed per gram of sample and relative pressure is presented in Fig. 7. The higher $\mathrm{N}_{2}$ adsorbed values over the $\mathrm{Al}_{2} \mathrm{O}_{3}$ suggests a larger area for the surface reactions.

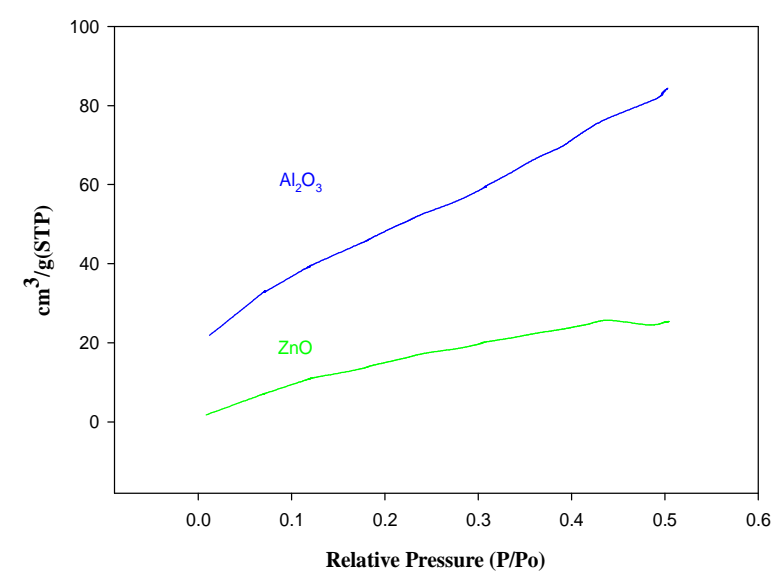

Figure 7. Adsorption isotherm $\left(-175{ }^{\circ} \mathrm{C}\right.$, adsorbate temperature) over $\mathrm{Al}_{2} \mathrm{O}_{3}$ and $\mathrm{ZnO}$ catalyst (surface area comparison)

\section{Conclusion}

The used edible oil contains a number of degraded organic particles and thus not fit for the human feedings. This used oil can be converted into light organic fractions and ideally it is desired at minimum possible temperatures in order to save energy. Here after basic physical filtrations the cracking temperature was examined over $\mathrm{Al}_{2} \mathrm{O}_{3}$ and $\mathrm{ZnO}$ catalysts. Highest conversion over the $\mathrm{ZnO}$ was $81 \%$, but it was achieved at a comparatively high temperature of $450^{\circ} \mathrm{C}$ whereas the rest of the parameters were same as for $\mathrm{Al}_{2} \mathrm{O}_{3}$, i.e., catalyst loading (8 wt \%), heating rate $\left(10{ }^{\circ} \mathrm{C} / \mathrm{min}\right)$, and resident time $(60$ $\mathrm{min})$. On the other hand, the maximum conversion noted over the $\mathrm{Al}_{2} \mathrm{O}_{3}$ was $71 \%$ at a temperature of $390^{\circ} \mathrm{C}$, and the remaining reacting condition was same as was for the $\mathrm{ZnO}$ catalyst. Above $390^{\circ} \mathrm{C}$ the activity showed a decreasing trend or the reaction rate decreases. In general, the collected organic products species had similar fuel properties. The XRD analysis of the $\mathrm{Al}_{2} \mathrm{O}_{3}$ and $\mathrm{ZnO}$ samples displayed the standard patterns. The surface area of the $\mathrm{Al}_{2} \mathrm{O}_{3}$ is much higher than the $\mathrm{ZnO}$ catalyst and could be a main reason behind the greater activity at lower temperature ranges.

\section{Acknowledgement}

Authors greatly acknowledge the Board of Advance Studies and Research (BOASAR) office for providing the financial help and keeping the record of all official documents. We are also thankful to the Chemical Engineering Department for technical, and safety guidance.

\section{Conflict of Interest}

The authors declare that there is no conflict of interest. 


\section{References}

1. F. Umbach, Energ. Policy, 38 (2010) 12240.

https://doi.org/10.1016/j.enpol.2009.01.010

2. M. Shyamsundar, S.Z.M. Shamshuddin and J.N. Sahu, Korean J. Chem. Eng., 30 (2013) 2186.

https://doi.org/10.1007/s11814-0130177-6

3. G. W. Huber and A. Corma, Angew. Chem. Int. Ed., 46 (2007) 7184. https://doi.org/10.1002/anie.200604504

4. N. Boz, N. degirmenbasi and D.M. Kalyon, Appl. Catal. B Environ., 89 (2009) 590.

https://doi.org/10.1016/j.apcatb.2009.01.026

5. F. Abnisa, W. M. A Wan Daud, A. A. A Niya, B.S Ali and J.N Sahu, Energ. Fuels, 28 (2014) 3074. https://doi.org/10.1021/ef5003952

6. Q. Zhang, T. Wang, Y. Xu, Q. Zhang and L. Ma, Energ. Convers. Manag., 77 (2014) 262.

https://doi.org/10.1016/j.enconman.2013 .09 .032

7. J. M. Nazzal, J. Anal. Appl. Pyrol., 62 (2002) 225.

https://doi.org/10.1016/S0165-

2370(01)00119-X

8. F. Che, I. Sarantopoulos, T. Tsoutsos and V. Gekas, Biomass Bioenerg., 36 (2012) 427.

https://doi.org/10.1016/j.biombioe.2011. 10.005

9. D. Wen, H. Jiang and K. Zhang, Mater. Int., 19 (2009) 273. https://doi.org/10.1016/j.pnsc.2008.09.001

10. V. Krishnamoorthy, R. Dhanasekaran, D. Rana, S. Saravanan and B. R. Kumar, Energ. Convers. Manag., 156 (2018) 337.

https://doi.org/10.1016/j.enconman.2017 .10 .087

11. C. Chen, Y. Zhao and B. Zhao, Environ. Sci. Technol., 52 (2018) 1081. https://doi.org/10.1021/acs.est.7b05600
12. D. Pradhan, R. K. Singh, H. Bend and R. Mund, Energ. Convers. Manag., 108 (2016) 529.

https://doi.org/10.1016/j.enconman.2015 .11 .042

13. S. F. Arifin, Arifin S.F, Production of Biodiesel from Waste Cooking Oil and RBD Palm Oil Using Batch Transesterification Process, Thesis., University Malaysia Pahang, (2009).

http://umpir.ump.edu.my/id/eprint/861/1 /Siti_Fatimah_Arifin.pdf

14. T. L. Chew and S. Bhatia, Biores. Technol., 99 (2008) 7911. https://doi.org/10.1016/j.biortech.2008.0 $\underline{3.009}$

15. A. Gashaw and A. Teshita, Inter. J. Sustain. Green Energ., 3 (2014) 92.

https://doi: 10.11648/j.ijrse.20140305.12

16. X. Dupain, D. J. Costa, C. J. Chaverien, M. Makkee and J. A. Moulijn, Appl. Catal. B: Environ., 72 (2007) 44.

https://doi.org/10.1016/j.apcatb.2006.10. $\underline{005}$

17. K. D. Maher and D. C. Bressler, Biores. Technol., 98 (2007) 2351.

https://doi.org/10.1016/j.biortech.2006.1 $\underline{0.025}$

18. Y. K. Ong and S. Bhatia, Energ., 35 (2019) 111.

https://doi.org/10.1016/j.energy.2009.09. $\underline{001}$

19. J. Xu, J. Jiang, T. Zhang and W. Dai, Energ. Fuels, 27 (2013) 255. https://doi.org/10.1021/ef3018173

20. N. Y. Yahya, N. Ngadi, M. Jusoh and N. A. A. Halim, Energ. Convers. Manag., 129 (2016) 275.

https://doi.org/10.1016/j.enconman.2016 .10 .037

21. Y. K. Ong and S. Bhatia, Energ., 35 (2010) 111.

https://doi.org/10.1016/j.energy.2009.09.001

22. E. Vonghia, D. G. B. Boocock, S. K. Konar and A. Leung, Energ. Fuels, 9 (1995) 1090.

https://doi.org/10.1021/ef00054a024 
23. F. M. Wako, A. S. Reshad, M.S. Bhalerao and V. V. Goud, Ind. Crops Prod., 118 (2018) 282.

https://doi.org/10.1016/j.indcrop.2018.0 3.057

24. L. I. Li, Z. Ding, K. Li, J. Xu, F. Liu, S. Liu, S. Yu, C. Xie and X. Ge, J. Anal. Appl. Pyrol., 117 (2016) 268. https://doi.org/10.1016/j.jaap.2015.11.006

25. J. M. Nazzal, J. Anal. Appl. Pyrol., 62 (2002) 225.

https://doi.org/10.1016/S0165-

2370(01)00119-X
26. S. Mosallanejad, B. Z. Dlugogorski, E. M. Kennedy and M. Stockenhuber, ACS Omega, 3 (2020) 5362. https://doi.org/10.1021/acsomega.8b00201

27. K. Djebaili, Z. Mekhalif, A. Boumaza and A. Djelloul, J. Spectrosc., 3 (2020) 5362.

https://doi.org/10.1155/2015/868109

28. S. Fakhari, M. Jamzad and H. K. Fard, Green Chem. Lett. Rev., 3 (2019) 19.

https://doi.org/10.1080/17518253.2018.1 547925. 